\title{
Hydrogeochemical and isotopic constraints on the origin and evolution of groundwater from a Quaternary aquifer in the Shule River Basin, Northwest China
}

\author{
LIHENG WANG ${ }^{12}$ Y ANHUI DONG ${ }^{123}$
}

'Key Laboratory of Shale Gas and Geoengineering, Institute of Geology and Geophysics, Chinese Academy of Sciences, Beijing 100029, China, wlheng7@163.com

Innovation Academy for Earth Science, Chinese Academy of Sciences, Beijing, 100029, China

College of Earth and Planetary Sciences University of Chinese Academy of Sciences, Beijing 100049, China; dongyh@mail.iggcas.ac.cn

Stable isotopic $(\delta D$ and $\delta \mathrm{O})$ and major ions were employed to constrain the geochemical evolution and sources of groundwater recharge in the arid Shule River Basin, Northwestern China, where extensive groundwater extraction occurs for irrigation and municipal use. A total of 54 specimens were collected in 2014 to 2015 from upstream to downstream in the watershed which can be divided into three parts according to geographical characteristics, the Changma unit (Qilian Mountains area), the Yumen unit (the piedmont alluvial basins) and Guazhou plains unit. The quality of groundwater in Changma was generally good with low salinity and depleted in heavy isotopes, with mean values of $12.1 \% 0 \delta \mathrm{O}$ and $-74 \% 0 \delta \mathrm{D}$. It mainly originated from precipitation in the Qilian Mountains because their isotopes were very similar. Lateral flow from Changma acted a primary source of groundwater recharge in the Yumen unit, while direct recharge by infiltration of local precipitation can be neglected. Dissolution of minerals within the aquifer material (e.g., halite, calcite, dolomite, and gypsum) was mainly source of groundwater salinity. Therefore, strong linear relationships were found between $\mathrm{Na}^{+}$and $\mathrm{Cl}$ and between $\mathrm{Ca}^{2+}+\mathrm{Mg}^{2+}$ and $\mathrm{SO}_{4}+\mathrm{HCO}_{3}$, with stoichiometry ratios of approximately 1:1 in both cases. Groundwater in Guazhou unit may be recharged by seepage of the Shule River water. The ion-exchange reaction played a dominant role in hydrogeochemical evolution and causes a good linear relationship between $\left(\mathrm{Mg}^{2}+\mathrm{Ca}^{2}\right)-\left(\mathrm{SO}_{4}+\mathrm{HCO}_{3}\right)$ and $\left(\mathrm{Na}+\mathrm{K}^{+}\right)$$\mathrm{Cl}$ with a slope of -0.89 and also results in positive CAI 1 and CAI 2. At last, a conceptual model was developed based on hydrogeochemical and isotopic analysis. and the hydrologic circulation process in the Shule River Basin has been initially identified.The results should facilitate integrated management of groundwater and surface water resources in the study area. 